\title{
Integrating food systems and local food in family and consumer sciences: Perspectives from the pilot Extension Master Food Volunteer program
}

\author{
J. Dara Bloom, ${ }^{a}$ * Joanna Massey Lelekacs, ${ }^{\mathrm{b}}$ and Gretchen L. Hofing ${ }^{\mathrm{c}}$ \\ North Carolina State University
}

Robyn Stout ${ }^{d}$

Center for Environmental Farming Systems, North Carolina State University

\author{
Morgan Marshall e and Kristin Davis ${ }^{\mathrm{f}}$ \\ North Carolina Cooperative Extension
}

\begin{abstract}
Submitted March 10, 2019 / Revised June 3, July 11, August 20, and August 30, 2019 / Accepted September 4, 2019 /
Published online February 19, 2020

Citation: Bloom, J. D., Lelekacs, J. M., Hofing, G. L, Stout, R., Marshall, M., \& Davis, K. (2020). Integrating

food systems and local food in family and consumer sciences: Perspectives from the pilot Extension Master

Food Volunteer program. Journal of Agriculture, Food Systems, and Community Development, 9(2), 197-220.

https://doi.org/10.5304/jafscd.2020.092.013
\end{abstract}

Copyright (C 2020 by the Authors. Published by the Lyson Center for Civic Agriculture and Food Systems. Open access under CC-BY license.

\begin{abstract}
Cooperative Extension programs across the United States are embracing food systems and local food
\end{abstract}

a $*$ Corresponding author: J. Dara Bloom, Assistant Professor and Local Foods Extension Specialist, Department of Agricultural and Human Sciences, North Carolina State University; 512 Brickhaven Drive, Raleigh, NC 27695 USA; +1-919-515-8475; dara bloom@ncsu.edu

b Joanna Massey Lelekacs, Local Food Program Manager, NC State Extension, North Carolina State University.

Lelekacs is now Director of Education, North Carolina

Botanical Garden, University of North Carolina at Chapel Hill.

${ }^{c}$ Gretchen L. Hofing, MPH, RD, NBC-HWC, SNAP-Ed

Steps to Health Coordinator, Department of Agricultural and

Human Sciences, North Carolina State University.

Hofing is now Program Coordinator, Duke Integrative Medicine.

d Robyn Stout, NC 10\% Campaign State Coordinator, Center for Environmental Farming Systems, North Carolina State University. as a new topic area. Previous studies indicate that successful local food programming requires crossprogram collaboration. However, research in this area has underrepresented Extension educators from non-agricultural program areas, although understanding their perspectives is key to fostering

e Morgan Marshall, Extension Area Agent, Family and Consumer Sciences, North Carolina Cooperative Extension, New Hanover, Brunswick, and Pender County Centers.

Marshall is now Marketing and Event Assistant, Asheville Event Co.

${ }^{\mathrm{f}}$ Kristin Davis, Extension Agent, Family and Consumer Sciences, North Carolina Cooperative Extension, Mecklenburg County Center.

\section{Funding Disclosure}

The development of the Extension Master Food Volunteer program was made possible through funding from $\mathrm{NC}$ Cooperative Extension's FCS Program, the Department of Agricultural and Human Sciences, and a grant from the NC ECA and FCS Foundation. 
cross-program collaboration. The case study presented in this paper examines qualitative evaluation data from the pilot year of the NC State Extension Master Food Volunteer (EMFV) program, which provides training in food systems and local food to Family and Consumer Sciences (FCS) educators and their volunteers. Data from semistructured interviews with educators in the pilot program and from focus groups with their volunteers provide the opportunity to explore areas of intersection and divergence between local food and the FCS program area in order to determine how to best integrate FCS and local food. Findings suggest that integrating local food into FCS programming will require special attention to potentially controversial issues that require educators and volunteers to communicate with the public about scientific issues that also invoke personal values, such as pesticide use and genetic engineering. We also found that educators and volunteers felt that promoting local food was not always compatible with an FCS focus on healthy eating. Overall, this case study demonstrates the potential to engage FCS educators and volunteers in cross-program, community-based food system projects, and to provide public education in the growing field of food systems and local food.

\section{Keywords}

Local Food, Cooperative Extension, Family and Consumer Sciences, Volunteers, Food Systems Training

\section{Introduction and Literature Review}

\section{Introduction: Local Food, Cooperative Extension, and Family and Consumer Sciences}

Research has shown that Cooperative Extension educators across the country have become increasingly involved in food systems work, focusing specifically on local foods (Benson, 2014; Bloom, Lelekacs, Dunning, Piner, \& Brinkmeyer, 2017; Ingerson, Jayaratne, Wymore, \& Creamer, 2014; Lelekacs et al., 2016; McGuirt et al., 2018; Perez \& Howard, 2007; Thomson, Radhakrishna, \& Bagdonis, 2011; Thomson, Radhakrishna, Maretzki, \& Inciong, 2006). This interest mirrors the growing consumer interest and corresponding research in local food systems as vehicles for promoting community economic development, supporting farmers, and increasing access to healthy food (Bauman, Thilmany McFadden, \& Jablonski, 2018; Koch et al., 2017; Low et al., 2015). A growing body of literature identifies Cooperative Extension as being ideally situated to take leadership in local food system development (Clark et al., 2017; Colasanti, Wright, \& Reau, 2009; Dunning et al., 2012; Morgan \& Fitzgerald, 2014; Raison, 2010). This is because Cooperative Extension has traditionally provided training and programs that coincide with the primary areas of local food system development, including (1) working with growers and gardeners; (2) supporting local markets;

(3) educating youth about agriculture and food; and

(4) providing guidance on home and commercial processing and preservation (Gould, Steele, \& Woodrum, 2014). Local food, therefore, crosses Cooperative Extension program areas, which include Agriculture and Natural Resources (ANR; encompassing horticulture and livestock), 4-H youth programming, and Family and Consumer Sciences (FCS). In addition, Cooperative Extension has a large presence across the country; according to the USDA National Institute of Food and Agriculture, Extension operates offices in most of the 3,000 counties nationwide (USDA NIFA, n.d.-a), connecting communities to more than 100 landgrant universities (USDA NIFA, n.d.-b).

Despite the gains that have been made to integrate local food systems into Cooperative Extension, research still indicates that Extension educators consistently express needs for resources and education to help them accomplish these goals (Bloom et al., 2017; Lelekacs et al., 2016; Thomson et al., 2011). Before educators can engage communities to work on local food system projects and programs, they need education and capacity-building related to what defines a food system and how to foster high-performing local food systems (Bloom et al., 2017; Lelekacs et al., 2016).

Noting the complexities of understanding the food system and the nontraditional stakeholders who are interested in the field (such as public health practitioners), researchers suggest that a systems approach that crosses program areas is the best way to engage Cooperative Extension educa- 
tors (Bloom et al., 2017; Dunning et al., 2012; Morgan \& Fitzgerald, 2014). However, surveys and focus groups conducted to better understand Extension educators' role in local food systems have most often targeted educators who are already explicitly involved in local food work (most often from the ANR program area), resulting in lower response rates from FCS educators (Benson, 2014; Clark et al., 2017; Ingerson et al., 2014). ${ }^{1}$ One exception is a study by Thomson et al. (2011), who sent a survey about local food perceptions to the entire population of Extension educators in New York, New Jersey, and Pennsylvania. This study had higher response rates from FCS educators than the studies cited above, although still lower than agriculture educators $(28.8 \%$ and $45.9 \%$, respectively). Another exception is McGuirt et al. (2018) and Seguin et al. (2018), both of whom targeted nutrition educators. However, the McGuirt et al. study evaluated a specific program that offered cost-offset community supported agriculture $(\mathrm{CSA})^{2}$ boxes to participants in nutrition education classes, rather than exploring the larger issues involved in integrating local food projects and issues into the FCS program area within Cooperative Extension. While Seguin et al. were connected to the same CSA project, they asked nutrition educators specific questions about their perceptions of local food and its integration in Cooperative Extension programming. Their study was a first step toward understanding the relationship between local food and non-agricultural Extension program areas. Seguin et al. found that nutrition educators were supportive of local food due to its resonance with their "way of life" and supporting farmers. At the same time, they found that educators identified barriers to integrating local food in their programming due to the seasonality of local food, its potential for spoilage, and perceived price issues. The current study builds on these findings to expand the body of research that explores local food program implementation in non-agricultural program areas in Cooperative Extension. Our study differs from both the McGuirt and Seguin studies by focusing on Family and Consumer Sciences (formerly referred to as Home Economics) educators and their volunteers, rather than nutrition educators. FCS educators conduct nutrition education in the context of overall FCS programming, which also includes food safety, cooking skills, home food preservation, and working with community partners to change community food environments. In addition, we examine FCS educators' and their volunteers' perspectives of local food within the context of a specific program that provides training, resources, and program implementation opportunities on this topic. We contend that effectively promoting a crossprogram approach to local food programming in Extension requires understanding the barriers to and opportunities for integrating local food into non-agricultural program areas such as FCS.

While FCS educators are typically underrepresented in research related to local food in Extension, there are many intersections between FCS programming and local food work. Developments in the field of public health and previous research on consumers' and educators' local food perceptions can inform those interested in how local food might align with this program area. Washburn (2017) describes how, beginning in 2015, the federally funded nutrition education programs that have long served as the hallmark of FCS programming, such as the Expanded Food and Nutrition Education Program (EFNEP) and the Supplemental Nutrition Assistance Program Education (SNAPEd), began to emphasize the need to go beyond direct education to include policy, systems, and environmental changes (PSE; see also HaynesMaslow, Osborne, \& Jilcott Pitts, 2018). These PSE strategies focus on changing community food environments to make healthy food more available,

\footnotetext{
${ }^{1}$ Benson (2014) reported a 37.7\% response rate for ANR educators, compared to 19\% for FCS; Clark et al. (2017) had 33.3\% representation from ANR, compared to $19.6 \%$ for FCS; and Ingerson et al. (2014) had a 35.9\% response rate from Agriculture educators, compared to $12.8 \%$ FCS (combined with County Extension directors and program associates).

${ }^{2}$ Community supported agriculture is a marketing arrangement where farmers typically sell customers a "share" of the harvest before the season begins. In return, customers receive a box or share of produce on either a weekly or biweekly basis throughout the season (Woods, Ernst, \& Tropp, 2017).
} 
affordable, and accessible to consumers (Committee on Accelerating Progress in Obesity Prevention, Food and Nutrition Board, \& Institute of Medicine, 2012). For example, PSE changes might include offering healthier food through school cafeterias, congregate nutrition sites, food pantries, corner stores, faith communities, or other community sites, or working with these sites to build walking trails or other opportunities for physical activity (Haynes-Maslow et al., 2018). Often, direct education in the form of cooking demonstrations or taste tests accompanies PSE changes in community locations to help support consumers as they increase their consumption of healthy food. As a result, many PSE projects include local food, such as working with farmers markets to increase community access, connecting food pantries with sources of local food, or designing nutrition education in school settings to incorporate gardening (Haynes-Maslow et al., 2018; Koch et al., 2017).

Research on consumer and Cooperative Extension perceptions of local food systems also suggests synergy between FCS topic areas and local foods. For example, Perez and Howard (2007) found in their survey of consumers in California that consumers' primary food system concerns were related to food safety and nutrition, both of which are traditional FCS program areas. They also found that consumers were interested in the environmental impacts of how food is produced, an issue that points to a potential new role for FCS educators to address. This finding is consistent with other research findings documenting growing consumer interest in "sustainable diets," or in understanding the social and environmental implications of their dietary choices (Gussow, 1999; Gussow \& Clancy, 1986; Merrigan et al., 2015; Reynolds, Buckley, Weinstein, \& Boland, 2014). Studies also indicate that FCS educators believe their role intersects with the food system through improving access to healthy food for low-income consumers, including increasing the inclusion of marginalized populations in local food programs (Clark et al., 2017; McGuirt et al., 2018; Seguin et al. 2018; Thomson et al., 2011).

To expand our understanding of the intersec- tion between local food and FCS programming, we ask: How do FCS Extension educators and volunteers in their programs perceive the value of food systems education and its relationship to traditional FCS programming? We address this research question through a case study of the evaluation of a pilot Extension program for FCS educators and their volunteers that includes training in food systems in addition to traditional FCS topic areas.

\section{Applied Research Methods}

\section{Study Context}

To explore the intersection between FCS programming and local food, we focus on qualitative data from the evaluation of the pilot NC State Extension Master Food Volunteer (EMFV) program. The EMFV program provides FCS educators with a training curriculum to prepare volunteers to support FCS programming in their counties. The EMFV program helps FCS educators strengthen their programming in food and nutrition, learn about food systems and local food, and expand their capacity to serve multiple counties by engaging with volunteers. In 2015-2016, the lead author assembled a team of Extension specialists and FCS educators (including the co-authors) to develop the NC State Extension Master Food Volunteer (EMFV) program and training curriculum. The EMFV curriculum consists of 10 modules: (1) Cooking Skills; (2) Cooking Demonstrations; (3) Food Safety; (4) Nutrition; (5) Food Systems and Local Food; (6) Teaching Strategies; (7) Evidencebased Programming; (8) Changing Health Behaviors; (9) History of Extension and FCS; and (10) Diversity, Inclusion and Equity. The entire curriculum requires 30 hours of training to complete, and the Food Systems and Local Food section of the curriculum $^{3}$ takes approximately 6 to 8 hours. The learning objectives for the Food Systems and Local Food module are that participants will:

1. Understand the place-based nature of local food and identify which values of local food systems are relevant in their county or region.

\footnotetext{
${ }^{3}$ For a summary of the content of Food Systems and Local Food module of the EMFV curriculum, please see Appendix A.
} 
2. Be able to define the sectors of the food system and cite example projects or Cooperative Extension programs that are working to develop local food systems in North Carolina.

3. Be familiar with common definitions of local food and why consumers are interested in local food.

4. Be able to answer consumers' questions about the benefits and impacts of buying local food.

5. Be able to describe the differences between standards, certifications, and labels, and be familiar with some common certifications and labels.

The program was piloted with seven FCS educators in 2016-2017. The seven educators in the pilot program were trained in person in the EMFV curriculum in May 2016 by a team, which included the co-authors, of 13 Extension specialists and one Extension educator who had contributed to the curriculum. An evaluation of the program was conducted in 2017. Revisions were made to the curriculum based on this feedback from educators and volunteers, including the incorporation of new activities developed by educators in the pilot program (discussed more fully in the results section). The curriculum was then sent for external review by seven experts in the fields of local food and FCS. The curriculum was finalized in 2017, and the program was rolled out statewide in 2018. This study focuses on educators' and volunteers' perceptions of the intersection between FCS and local food based on their experiences in the pilot EMFV program.

While many other states offer a similar volunteer program (including Kansas State University and Virginia Polytechnic Institute and State University [Virginia Tech]), NC State Extension's curriculum is unique in including a section on Food Systems and Local Food. Part of the justification for developing a Food Systems and Local Food module for the EMFV training curriculum was due to the strong emphasis on local food within NC
Cooperative Extension. ${ }^{4}$ Local Food was named a Flagship Program for NC Cooperative Extension in 2012, and every county has a designated local food coordinator (Dunning et al., 2012; Ingerson et al., 2014). Extension specialists have offered local food training and program support for many years, both as part of the Flagship program and preceding this designation. Offerings have included training at in-service events, promotion of the NC 10\% Campaign, a graduate-level course for Extension educators, and an online, professional development certificate program about local food systems (Bloom et al., 2017; Dunning et al., 2012; Ingerson et al., 2014; Lelekacs et al., 2016). For these reasons, it was important that a curriculum designed to educate and support FCS educators and their volunteers in North Carolina include information about food systems and local food.

\section{Sample}

The seven FCS Extension educators in the pilot worked in 11 different counties with regional variation across North Carolina. However, two educators were excluded from this study because they had not yet trained their volunteers at the time of the evaluation. A total of 25 volunteers participated in the pilot year of the EMFV program. Except for two volunteers in County 2, the FCS educators and their volunteers were all females. All the educators who participated in the evaluation were white except for one Latina, and these educators worked with a total of seven volunteers who were African American, two who were Latina, and 16 who were white. A summary of county demographic and agricultural characteristics is provided in Appendix $B$ to provide context to the subsequent analysis.

As Appendix B shows, all five counties included in the evaluation either had strong agricultural sectors or had experienced large growth in the local food sector between 2007 and 2012. Counties 3 and 5 had the largest mean farm size (431 acres [174 hectares] and 340 acres [138 ha], respectively) and had experienced the largest sales growth in this area ( $+40 \%$ and $+25 \%$, respectively). Counties 1 and 5 had the most direct-to-consumer sales

\footnotetext{
4 The Food Systems and Local Food section of the EMFV curriculum is available for purchase by other states for inclusion in their programming. Adaptations are needed to include state-specific information about agriculture and food systems.
} 
(US\$382,000 and US\$482,000, respectively) and had experienced the largest growth in this area between 2007 and 2012 (+96\% and $+114 \%$, respectively). County 2 experienced the most growth in the number of farms selling direct to consumers from 2007 to $2012(+76 \%$; data are unavailable about direct consumer sales in 2012 for this county). County 4 had the largest number of farms (638) and the largest number of farms selling direct to consumer (73), and also the smallest average farm size ( 93 acres or 38 ha). County 4 was the only one that had experienced a decline in direct sales to consumers between 2007 and 2012 $(-59 \%)$, with County 1 experiencing the greatest increase in this category ( $+96 \%$ ). Given that these counties all either had strong agricultural systems (Counties 3, 4, and 5) and/or exhibited growth in local food indicators (Counties 1,2, and 5), we expected that training and resources focused on food systems and local food would be relevant to Extension educators and volunteers.

\section{Methods}

We evaluated the program after educators and volunteers had participated in the pilot for one year to assess their perceptions of the program's curriculum and implementation. The lead author conducted semistructured interviews in the summer of 2017 with the five educators who had trained volunteers. The lead author also conducted five focus groups with 17 participating volunteers who had been trained by these five educators. All interviews and focus groups were audio-recorded and transcribed; on average, they lasted one hour. The questions in both the interviews and focus groups were designed to learn about the educators' and volunteers' perceptions of the curriculum and implementation of the EMFV program. The participants were not asked specifically about the Food Systems and Local Food module of the curriculum, but rather more generally about which parts of the training they liked the best, which they liked the least, and what they would change. ${ }^{5}$ We did not ask questions specifically about the Food Systems and Local Food module of the curriculum because the purpose of the evaluation was to gather feedback on the entire training curriculum and program. Instead, we analyzed the interview and focus group transcripts to see where educators and volunteers independently mentioned this area of the training and curriculum. This allowed us to see how educators and volunteers reacted to the inclusion of these topics in a program designed to provide training in FCS topic areas and how they perceived the value of these topics. The extent to which the Food Systems and Local Food module was referred to by educators and volunteers, therefore, can be seen as an indicator of the salience of the topic to the participants. The lead author developed a codebook, and two independent coders analyzed the transcripts using NVivo 11 software. ${ }^{6}$ The lead author then reconciled the codes and analyzed emerging themes in terms of educators' and volunteers' reactions and responses to the Food Systems and Local Food module, and perceptions more generally about food systems issues as related to traditional FCS programming. This evaluation was reviewed and approved by the NC State University Institutional Review Board, \#6078.

\section{Results}

Although neither Extension educators nor volunteers were asked directly about food systems and local food, the responses that they offered to questions about their satisfaction with the curriculum and training implementation shed light on many of the themes that were identified in the review of the literature. These include (1) the need for training in food systems and local food; (2) interest in crossprogram collaboration; (3) controversial issues in the food system; and (4) the intersection of local food programming and food insecurity.

\section{Need for Food Systems Training}

Three of the five educators reported that their favorite part of the curriculum was the Food Systems and Local Food module. This included an educator who was already interested in and familiar with local food in County 2, as well as two educators who were less familiar with the topic. For

\footnotetext{
${ }^{5}$ For more information, please see the Interview Guide (Appendix C) and the Focus Group Guide (Appendix D).

${ }^{6}$ To see the codebook, please see Appendix E.
} 
example, the educator from County 3 responded to a question about what stood out for her from the training by saying,

The thing that I still really think about is the food system stuff, just because I had never really addressed it prior to that time. ... Definitely something that our participants want to know or that are very interested in, so I'm glad I got that experience, and it just seems like it was the first time I've been exposed to that information.

This sentiment was echoed by a third educator in County 4, who said,

Well, for me, it was my first experience with learning about food systems. I mean I kind of had a general idea about it, but I didn't know enough to be able to teach it to someone else... It really made me feel a lot more comfortable with talking to other people about local food.

These educators clearly valued learning about food systems and local food more generally, especially for those who recognized interest and demand in their county and now felt more prepared to address that interest.

Volunteers in two focus groups also directly mentioned the Food Systems and Local Food module when asked about their favorite parts of the curriculum. For example, one volunteer in County 4 said of this module, "You know I did not know the local thing. That was very interesting to me. The processing, the food banks, and what was the wheel thing? You know I never really thought about that. ... I mean every farmer doesn't go to the local farmers markets, so how does their product get different places?" The "wheel thing" this volunteer refers to is a diagram of the food system that is used to teach about the different sectors. In this quote, the volunteer demonstrates an appreciation for learning not just about local food, but about the bigger picture of how the food system works. While one volunteer in County 2 expressed disappointment that the curriculum seemed more focused on "knowing where the food came from," rather than on cooking, other volunteers expressed increased knowledge in this area and correspondent behavior changes. These behavior changes often overlapped with other areas of the curriculum. For example, one volunteer in County 3 mentioned increasing her fruit and vegetable consumption in response to the Nutrition module of the curriculum, but she also reported that she had begun to frequent a local farm stand more often and to try new foods, in this case, spaghetti squash. This volunteer and one in County 4 both reported that because of the training, they now asked the farmers at their local stands which products were local and which were coming from other regions.

\section{Interest in Cross-Program Collaboration}

While both educators and volunteers appreciated the Food Systems and Local Food module of the curriculum, it was a new area for many of them. As a result, they either requested additional training or implied that they were not ready to teach it on their own. The educator in County 3 expressed that while she felt she learned a lot, she also felt that she learned just enough to be able to communicate better with the agriculture educator in her county. When asked if she found the food systems training useful, she responded,

Definitely, because ... I can have intelligent conversations with the ag educators about what I need. Because I have that little bit of knowledge, and I'm like, 'This is what I need from you. It's something along this topic, I know you are better equipped for this,' but then I have the direction for them to go.

This quote illustrates how this training also helped to promote another goal in local food Extension work, cross-program collaboration. The County 3 FCS educator relied on the agriculture educator to provide resources about local food in their county that she could share with her volunteers. A volunteer from this county also mentioned directing program participants to the horticulture educator when they asked her questions about growing or planting gardens. The fact that participants in FCS programs also ask about growing food indicates that consumers are increasingly 
interested in food systems issues and do not always recognize the boundaries that Extension program areas put in place. The County 5 educator expressed her interest in the potential for crossprogram collaboration by sharing her vision for having Extension Master Food Volunteers pair with Extension Master Gardeners, saying,

If I have a volunteer, like one volunteer from the Master Gardeners and one volunteer from the Extension Master Food Volunteer [program] to teach a class at preschool, it would be so awesome to see this person talking about an eggplant from the plant side and then this person showing about the nutrition and how to cook it, and let's do a food [taste] test, but together.

In this way, this educator hoped that the volunteers would see each other as partners, rather than competitors, something that she also mentioned in reference to collaborating with 4-H educators. In these ways, we can begin to see how the EMFV program spurred educators to think about how food systems could lead them to work more with their colleagues and form bridges to other program areas to meet consumers' and program participants' interests.

\section{Controversial Issues in the Food System}

The Food Systems and Local Food section of the EMFV training curriculum provided some introductory information about potentially controversial issues in the food system. This included organic agriculture and genetically modified organisms (GMOs), which are described briefly in a section about standards, certifications, and labels. The way that educators and volunteers talked about these issues in interviews and focus groups raised the question about volunteers' ability to put aside their personal opinions on controversial topics. To this end, there is a module in the EMFV curriculum called Programs that Work that explains what it means that Extension uses evidence and researchbased strategies and information. Every FCS educator who was interviewed as part of this evaluation brought up the issue of volunteers adhering to evidence and research-based information, and vol- unteers in all counties except County 1 mentioned it as well. However, most educators and volunteers brought this up as an issue more generally, or specifically in the context of sharing information related to nutrition, food safety, or home food preservation. Only the educators from Counties 2 and 4 and volunteers in Counties 3 and 4 mentioned this specifically as it related to food system issues. For example, the educator in County 2 said,

I still get a little nervous thinking about sending them out and then getting questions about more opinion-based things, because ... it makes me nervous, but it's like, if someone asks you about organic versus conventional or something like that, like you can't tell them ... [they should buy] one or the other.

The educator in County 4 expressed similar sentiments, and gave a specific example,

We were doing a grocery store tour, I had one of the EMFV volunteers helping. And they were talking about produce and how to find product of origin, and she pipes up and says so just go by the Clean 15 and the Dirty Dozen, or something like that. And while yes, that is one of the strategies that people can use, I didn't really think it was appropriate for the grocery store tour... it's really hard to get volunteers to stick to that best practices or best recommendations when they have a personal bias in a particular area.

In both of these cases, the educator expressed concern that volunteers had a hard time putting aside their personal opinions, especially when it came to questions related to pesticide use and organic agriculture.

Interestingly, while FCS educators expressed these concerns about their volunteers, the EMFV volunteers who participated in the focus groups consistently reinforced the idea that they should refer any questions they did not feel prepared to answer back to the educator with whom they worked. Volunteers mentioned taking this approach generally and specifically with food systems issues. For example, when asked if she 
ever gets questions during FCS programs about GMOs, a volunteer in County 3 responded, "No GMO. I haven't gotten any like that. If I get any like that, I direct them to [the FCS educator]." Volunteers in County 4 were the most vocal about these controversial issues, especially GMOs, as well as the question of personal opinion. For example, one volunteer made the statement,

I want to avoid the health fairs, because I don't like to dispute people on GMOs and stuff. I think that's a personal opinion. I don't think that it's a question where I would be comfortable sharing either way the research base, it's just because I don't know enough about it for one thing.

This volunteer made the statement that the issue was too "political" and was thus better avoided. However, another volunteer in the focus group in County 4 responded, "I mean you know there's just certain things that you mess with, and certain things that you don't, and our food is one of them," expressing her disapproval of GMO technologies. Despite the fact that this was an issue that volunteers did not seem to agree on in this county, they still made the point that questions on controversial issues should be referred back to FCS educators. As one said, "You'd better be darn tooting you know everything, or be knowledgeable. If you don't know, it's okay, just tell them... go talk to [the FCS educator]."

In addition to the issues identified here, volunteers' comments during the focus groups suggest that they may have unacknowledged biases that would keep them from being able to identify situations when they need to avoid offering personal opinions and should refer questions back to FCS educators. For example, in talking about issues of food insecurity, a volunteer in County 1 made the comment, "And now the kids these days, the moms don't want to cook, they're eating out fast food, they're huge, they're growing big because of hormones or whatever they're getting." This volunteer's reference to how children are "growing big because of hormones," may be referring to a controversial issue in agriculture, the use of hormones in livestock production, but without any reflection as to the research in this area that may or may not support this claim. The volunteer's comment also indicates stereotyping and bias against consumers' health circumstances, which could be influenced by socioeconomic status and other factors. This example indicates the possibility that volunteers have opinions and biases in topics related to agriculture and the food system that they do not necessarily recognize, and which they may share with program participants.

In response to these issues, the FCS educator in County 2 suggested creating an activity where volunteers are given different scenarios of being asked questions about food systems issues by program participants. She suggested that the value of this activity would be "because that helps them with recall. But it also helps me to see how they would really answer." Two additional training activities created in response to this suggestion were incorporated into the final curriculum. The confusion and nervousness on these topics that educators and volunteers expressed suggest the need for continued education to better clarify the research behind many controversial issues in the food system.

\section{Intersection of Local Food and Food Insecurity}

Food insecurity is another major topic that emerged from the interviews and focus groups that highlights themes related to the intersection of local food and FCS. Volunteers in all five counties mentioned a food access activity in the Food Systems and Local Food module of the curriculum as one of their favorite parts of the program. In this activity, volunteers are paired off and given different amounts of cash (US\$9, US\$7, and US\$5). They are sent to different types of stores (or perform a simulated activity in the classroom) and told to buy a healthy meal for a family of four. Volunteers reported that they found this to be a "fun," "most interesting," and "good" activity. As a volunteer in County 5 said, "It brought home to me that regardless of how much money you have, you can still prepare a healthy meal." A volunteer in County 3 made a similar statement, saying, "It helped everybody learn budgeting on a meal, because a lot of people, especially in this county, don't know how to budget fresh food in their 
budget." Volunteers in all of the counties expressed similar sentiments about this activity. They talked about how it helped reinforce concepts about nutrition and healthy eating, while also helping them to better understand experiences of poverty and food insecurity.

However, while it is often assumed that FCS educators' intersection with food systems issues is in integrating low-income consumers and working on issues of food access (Clark et al., 2017;

McGuirt et al., 2018; Seguin et al., 2018; Thomson et al., 2011), two volunteers in different counties pointed out the potential incompatibility between reaching these populations and promoting local food. For example, a volunteer in County 2 said, "To buy from the farmers market is expensive. And the emphasis is getting people to eat healthier, but it isn't necessarily eating fresh food." This volunteer identified a key tension in integrating local food into FCS programming, especially with low-income audiences. Although research shows that prices at farmers markets are not necessarily higher than at supermarkets (McGuirt, Jilcott, Liu, \& Ammerman, 2011), there is a perception that local food costs more. In some cases, this perception may be accurate, such as in urban areas where markets often cater to higher-end consumers and sell organic produce (Salisbury, Curtis, Pozo \& Durward, 2018). Either way, this perception influences consumer behavior, and while Extension educators want to provide the public with education about food systems and local food, the priority for FCS educators is to encourage people to eat healthily. As the FCS educator in County 4 quoted above said in response to one of her volunteers talking about the "Dirty Dozen" list,

That's kind of how I responded to that, was yes, there is a Dirty Dozen list, but we would rather you eat your fruits and vegetables regardless of that list as opposed to not eating it unless you can buy it organically.

Volunteers in County 4 also reflected on the need to prioritize health and nutrition before promoting local food. One volunteer suggested that seasonal food can have a place in educating lowincome consumers since it may be less expensive, but then also situated this idea within a larger nutritional message:

Because if it's grown in season-if we're eating when it's mature in season, it's cheaper ... if I was talking to a bunch of mothers who was on a very limited income, you know I wouldn't go into the part where you would immediately do fresh or garden or whatever. Getting a child to eat a vegetable is the priority.

This volunteer also emphasized the need to promote fruit and vegetable consumption regardless of whether the produce was canned, frozen, or fresh. In addition to recognizing the need to prioritize nutrition messaging, volunteers in County 4 were aware of the way the food environment limits access to healthy food. In this case, they talked about transportation in this rural county, indicating an awareness of how food access is a deeper issue than simply being able to afford or knowing how to cook healthy food (Ver Ploeg et al., 2009).

\section{Discussion}

An analysis of FCS educators' and EMFV volunteers' responses to the Food Systems and Local Food module of the EMFV curriculum, and their perceptions in general about these topics, highlights the continued training needs associated with integrating local food into traditional FCS Extension programming. While a quantitative, retroactive pre/post-survey delivered at the end of educator and volunteer trainings indicated that FCS educators and their volunteers gained knowledge on focal topics, in interviews and focus groups they verbally expressed the need for additional training. Specialists in this area are working to integrate food systems and local food training into NC Cooperative Extension's New Professional Orientation to establish it as one of the core elements of the FCS program area. In this way, educators would not see these materials for the first time as part of the EMFV program, but rather would have some familiarity with it earlier in their careers.

Findings indicated that FCS educators enjoyed collaborating with educators and volunteers who work in the agricultural field. Participants' comments about collaborations indicated both an inter- 
est in cross-program projects as well as a desire to maintain and delineate boundaries when it comes to responsibilities. Through these findings, we can begin to see how the EMFV program spurred educators to think about how food systems could lead them to work more with their colleagues and form bridges to other program areas to meet consumers' and program participants' interests. This observation also intersects with questions of food systems training, since several FCS educators requested that the agriculture or horticulture agent in their counties teach the Food Systems and Local Food section of the curriculum. This raises the question of whether educators who have not been trained specifically in this curriculum are prepared to teach these materials.

In this analysis, we also explored two of the principal areas where FCS programming may overlap with food systems concepts: working with lowincome audiences, and educating consumers about controversial food systems issues. In terms of food insecurity, all the volunteers in the pilot EMFV program were interested in this topic and were especially appreciative of an activity that gave them hands-on experience with food access issues. At the same time, volunteers in two counties questioned the compatibility of promoting local food to food-insecure populations and mentioned the importance of prioritizing messaging about healthy eating. Several volunteers also demonstrated their understanding of the deeper causes of food insecurity, including transportation in rural areas and other issues related to poverty. However, others fell back on assumptions and biases about people living in poverty, specifically that they do not know how to budget their finances or that they rely on fast food. The curriculum attempts to address this issue by emphasizing that food insecurity is not only a food systems issue, but rather is determined by poverty, which is a complex issue influenced by multiple factors. Analysis of volunteer focus group transcripts demonstrates interest expressed by volunteers in this topic, combined with the expression of some bias in this area, indicating the need for continued education on this topic.

When it comes to more controversial food systems issues, FCS educators expressed concern that volunteers would be unable to put aside personal opinions about issues such as GMOs or pesticides to provide the public with the type of evidencebased information deemed suitable for Cooperative Extension. While volunteers clearly demonstrated their understanding of the need to refer questions on these types of issues back to the educators with whom they work, they also expressed some confusion and unacknowledged biases on these topics. This issue highlights a potential conflict between traditional Extension education models and best practices for public education on controversial food system issues. One of the hallmarks of Cooperative Extension is its connection to the landgrant university system, where research on a wide array of agricultural and food systems issues takes place. As a result, Extension's reliance on evidencebased information informed by this science is often cited as one of its distinguishing attributes and is the topic of the Programs that Work section of the EMFV curriculum. Approaching consumer education by providing science-based information is known as the deficit model of communication, which assumes that providing consumers with scientific information will change their knowledge, attitudes, and behavior (Sturgis \& Allum, 2004). However, when it comes to topics such as genetic engineering, research has shown that people's attitudes are not wholly reliant on scientific knowledge, but are also influenced by cultural, economic, and social values that affect risk perception and trust in new technologies (Davison, Barns, \& Schibeci, 1997; Sturgis \& Allum, 2004). In addition, Guthman (2011) points out that the deficit model is also prevalent when talking about alternative food systems, including markets such as farmers markets and CSAs. Guthman criticizes the "if they only knew" rhetoric in the alternative food sphere, which assumes that consumers' failure to attend these types of alternative markets or to purchase organic, local food is due to a lack of understanding of food system issues. Guthman also demonstrates that this attitude often maps onto class and racial divides, with white activists attempting to educate people of color and low-income consumers about the food system. Therefore, applying the Extension approach of providing evidence-based information when related to GMOs, organic agriculture, pesticides, and other controversial food 
system issues may not be the best way to prepare educators and volunteers to interact with the public. To address this issue, our team is currently working with the Genetic Engineering and Society Center at NC State University to develop curricular materials that could be used within Extension, including as a continuing education module for the EMFV program. These materials will focus more heavily on how educators can communicate with consumers about controversial topics, rather than relying solely on the concept of providing evidence-based information. This disconnect between the deficit model of communication and the need for more nuanced communication on controversial food system topics is one that should be pursued in further Extension programming and research.

In keeping with the place-based nature of local food systems, one interesting finding from this study is the diversity of responses across counties and locations. County 4 appeared to be the most engaged in the focus groups when it came to food systems topics, followed closely by County 2 . If we refer to Table 1 (Appendix B), we can note that County 4 has a large number of small farms (638 farms, average 93 acres or $38 \mathrm{ha}$ ), and the greatest number of farms selling directly to the consumer (73), though it was also the only county in the sample to experience a decline in direct-to-consumer sales between 2007 and 2012 (-59\%). Nonetheless, this county clearly has a vibrant landscape of small farms with a tradition of selling direct to consumers. County 2 data about direct-to-consumer sales for 2012 is unavailable, making it hard to compare to other counties. However, it had the largest increase in the percent of farms selling direct to consumers between 2007 and 2011 of the counties in the sample $(+76 \%)$. This increase in direct farm sales also indicates a likely growth in interest in local food in this county, which may also be influenced by both the presence of retirees from other regions of the country and its proximity to a neighboring county with a large urban area. While these parallel increases may help to explain why the educators and volunteers in these counties had more responses related to the Food Systems and Local Food module of the EMFV curriculum, it does not totally explain why they appeared more engaged with local food than other counties. For example,
County 5 has the highest amount of direct-toconsumer sales (US\$482,000) and also saw the largest growth in this area between 2007 and 2012 $(+114 \%)$, followed by County $1(+96 \%)$; County 3 has the highest number of farmers markets and roadside stands (11). In this case, while context may help to explain some of the different reactions observed among educators and volunteers with regard to local food, it is also possible that the personal interests of both educators and volunteers are a factor that determines how relevant they consider these issues.

\section{Conclusion}

Our study indicates that while FCS educators and their volunteers value food systems education, further work is required to determine the best way to integrate local food into FCS programming. This research indicates that future efforts should focus on how to build cross-program collaborations that respect the expertise of each program area, while also illustrating points of intersection. In addition, special attention should be paid to potentially controversial issues that require educators and volunteers to navigate between providing evidence-based information and understanding the values that people bring to food systems decisions. It is also important to be aware of the potential incompatibility between local food systems and other FCS messaging, such as healthy eating. While our ability to make generalizations is limited by both our small sample size and the place-specific context of local food systems, we believe that this case study sheds insight into themes that should be further explored in Extension programming and research. Overall, the passion and dedication that FCS educators and their volunteers displayed about these topics and their commitment to working with their communities indicate great promise for promoting community engagement around local food through the FCS program area.

\section{Acknowledgments}

The authors would like to thank all the specialists, educators, and volunteers who have given their time to develop the program and serve their communities. We also appreciate the feedback from the anonymous JAFSCD reviewers. 


\section{References}

Bauman, A., Thilmany McFadden, D. , \& Jablonski, B. B. R. (2018). The financial performance implications of differential marketing strategies: Exploring farms that pursue local markets as a core competitive advantage. Agricultural and Resource Economics Review, 47(3), 477-504. https://doi.org/10.1017/age.2017.34

Benson, M. C. (2014). Exploring Extension involvement in farm to school program activities. Journal of Extension, 52(4); 4FEA4. Retrieved from https://www.joe.org/joe/2014august/a4.php

Bloom, J. D., Lelekacs, J. M., Dunning, R., Piner, A., \& Brinkmeyer, E. (2017). Local food systems course for Extension educators in North Carolina: Summary of an innovative program. Journal of Extension, 55(4), 4IAW2. Retrieved from https://www.joe.org/joe/2017august/iw2.php

Clark, J. K., Bean, M., Raja, S., Loveridge, S., Freedgood, J., \& Hodgson, K. (2017). Cooperative extension and food system change: Goals, strategies and resources. Agriculture and Human Values, 34(2), 301-316. https://doi.org/10.1007/s10460-016-9715-2

Colasanti, K., Wright, W., \& Reau, B. (2009). Extension, the land-grant mission, and civic agriculture: Cultivating change. Journal of Extension, 47(4), 4FEA1. Retrieved from https://www.joe.org/joe/2009august/a1.php

Committee on Accelerating Progress in Obesity Prevention, Food and Nutrition Board, \& Institute of Medicine. (2012). Accelerating progress in obesity prevention: Solving the weight of the nation. Washington, D.C.: National Academies Press. https://doi.org/10.17226/13275

Davison, A., Barns, I., \& Schibeci, R. (1997). Problematic publics: A critical review of surveys of public attitudes to biotechnology. Science, Technology, \& Human Values, 22(3), 317-348. https://doi.org/10.1177/016224399702200303

Dunning, R., Creamer, N., Lelekacs, J. M., O’Sullivan, J., Thraves, T., \& Wymore, T. (2012). Educator and institutional entrepreneur: Cooperative Extension and the building of localized food systems. Journal of Agriculture, Food Systems, and Community Development, 3(2), 99-112. https://doi.org/10.5304/jafscd.2012.031.010

Gould, F. I., Steele, D., \& Woodrum, W. J. (2014). Cooperative Extension: A century of innovation. Journal of Extension, 52(1). 1COM1. Retrieved from https://www.joe.org/joe/2014february/comm1.php

Gussow, J. D. (1999). Dietary guidelines for sustainability: Twelve years later. Journal of Nutrition Education, $31(4), 194$ 200. https://doi.org/10.1016/S0022-3182(99)70441-3

Gussow, J. D., \& Clancy, K. L. (1986). Dietary guidelines for sustainability. Journal of Nutrition Education, 18(1), 1-5. https://doi.org/10.1016/S0022-3182(86)80255-2

Guthman, J. (2011). "If they only knew": The unbearable whiteness of alternative food. In A. H. Alkon \& J. Agyeman (Eds.), Cultivating food justice: Race, class and sustainability (pp. 263-281). Cambridge, Mass.: The MIT Press.

Haynes-Maslow, L., Osborne, I., \& Jilcott Pitts, S. B. (2018). Best practices and innovative solutions to overcome barriers to delivering policy, systems and environmental changes in rural communities. Nutrients, $10(8), 1012$. https://doi.org/10.3390/nu10081012

Ingerson, K., Jayaratne, K. S. U., Wymore, T., \& Creamer, N. (2014). Extension educators' perceptions about the NC 10\% Local Food Campaign: Impacts, challenges, and alternatives. Journal of Extension, 52(2), 2FEA7. Retrieved from https://www.joe.org/joe/2014april/a7.php

Koch, P., Wolf, R., Graziose, M., Gray, H. L., Trent, R., \& Uno, C. (2017). FoodCorps: Creating Healthy School Environments. New York: Laurie M. Tisch Center for Food, Education \& Policy, Program in Nutrition, Teachers College, Columbia University. Retrieved from https:// foodcorps.org/about/impact/foodcorps-creating-healthy-school-environments-teachers-college/

Lelekacs, J. M., Bloom, J. D., Jayaratne, K. S. U., Leach, B., Wymore, T., \& Mitchell, C. (2016). Planning, delivering, and evaluating an extension in-service training program for developing local food systems: Lessons learned. Journal of Human Sciences and Extension, 4(2), 1-19. Retrieved from https://www.jhseonline.com

Low, S. A., Adalja, A., Beaulieu, E., Key, N., Martinez, S., Melton, A., ... Jablonski, B. B. R. (2015). Trends in U.S. local and regional food systems: A report to Congress (No. AP-068); p. 89). Washington, D.C.: U.S. Department of Agriculture, Economic Research Service. Retrieved from https://www.ers.usda.gov/publications/pub-details/?pubid=42807

McGuirt, J. T., Jilcott, S. B., Liu, H., \& Ammerman, A. S. (2011). Produce price savings for consumers at farmers' markets compared to supermarkets in North Carolina. Journal of Hunger \& Environmental Nutrition, 6(1), 86-98. https://doi.org/10.1080/19320248.2010.551031 
McGuirt, J. T., Jilcott Pitts, S. B., Seguin, R. A., Bentley, M., DeMarco, M., \& Ammerman, A. S. (2018). Perspectives on a local food access and nutrition education program from Cooperative Extension nutrition educators. Journal of Agriculture, Food Systems, and Community Development, 8(3), 105-122. https://doi.org/10.5304/jafscd.2018.083.002

Merrigan, K., Griffin, T., Wilde, P., Robien, K., Goldberg, J., \& Dietz, W. (2015). Designing a sustainable diet. Science, 350(6257), 165-166. https://doi.org/10.1126/science.aab2031

Morgan, K. T., \& Fitzgerald, N. (2014). Thinking collectively: Using a food systems approach to improve public health. Journal of Extension, 52(3), 3COM3. Retrieved from https://www.joe.org/joe/2014june/comm3.php

Perez, J., \& Howard, P. (2007). Consumer interest in food systems topics: Implications for educators. Journal of Extension, 45(4), 4FEA6. Retrieved from https://www.joe.org/joe/2007august/a6.php

Raison, B. (2010). Educators or facilitators? Clarifying Extension's role in the emerging local food systems movement. Journal of Extension, 48(3), 3COM1. Retrieved from https://joe.org/joe/2010june/comm1.php

Reynolds, C. J., Buckley, J. D., Weinstein, P., \& Boland, J. (2014). Are the dietary guidelines for meat, fat, fruit and vegetable consumption appropriate for environmental sustainability? A review of the literature. Nutrients, $6(6)$, 2251-2265. https://doi.org/10.3390/nu6062251

Salisbury, K., Curtis, K., Pozo, V., \& Durward, C. (2018). Is local produce really more expensive? A comparison of direct market and conventional grocery produce pricing. Journal of Food Distribution Research, 49(1), 13-21. https://doi.org/10.22004/ag.econ.274599

Seguin, R. A., McGuirt, J. T., Jilcott Pitts, S. B., Garner, J., Hanson, K. L., Kolodinsky, J., \& Sitaker, M. (2018). Knowledge and experience related to community supported agriculture and local foods among nutrition educators. Journal of Hunger \& Environmental Nutrition. Advance online publication. https://doi.org/10.1080/19320248.2018.1549520

Sturgis, P., \& Allum, N. (2004). Science in society: Re-evaluating the deficit model of public attitudes. Public Understanding of Science, 13(1), 55-74. https://doi.org/10.1177/0963662504042690

Thomson, J. S., Radhakrishna, R., \& Bagdonis, J. (2011). Extension educators' perceptions of the local food system. Journal of Extension, 49(4), 4RIB4. Retrieved from http://www.joe.org/joe/2011august/rb4.php

Thomson, J. S., Radhakrishna, R. B., Maretzki, A. N., \& Inciong, L. O. (2006). Strengthening community engagement toward sustainable local food systems. Journal of Extension, 44(4), 4FEA2. Retrieved from https://www.joe.org/joe/2006august/a2.php

U.S. Department of Agriculture, National Institute of Food and Agriculture (USDA NIFA). (n.d.-a). Cooperative Extension System. Retrieved February 4, 2020, from https://nifa.usda.gov/cooperative-extension-system

USDA NIFA. (n.d.-b). Extension. Retrieved February 4, 2020, from https://nifa.usda.gov/extension

Ver Ploeg, M., Breneman, V., Farrigan, T., Hamrick, K., Hopkins, D., Kaufman, P., .. Tuckermanty, E. (2009). Access to affordable and nutritious food-Measuring and understanding food deserts and their consequences: Report to Congress (Report No. AP-036). Washington, D.C.: United States Department of Agriculture, Economic Research Service. Retrieved from https://www.ers.usda.gov/publications/pub-details/?pubid=42729

Washburn, L. T. (2017). Engagement of health volunteers: A promising approach for meeting community needs. Journal of Extension, 55(3), 3COM1. Retrieved from https://www.joe.org/joe/2017june/comm1.php

Woods, T., Ernst, M., \& Tropp, D. (2017). Community supported agriculture-New models for changing markets. Retrieved from U.S. Department of Agriculture, Agricultural Marketing Service. Retrieved from https://www.ams.usda.gov/publications/content/community-supported-agriculture-new-models-changing-markets 


\section{Appendix A. Curriculum Description}

The materials included in the curriculum are four PowerPoint presentations (with scripts), one video, five participant engagement activities, and 17 handouts, described in detail in Table A1. These materials are available upon request from NC Cooperative Extension.

\section{Table A1. Contents of the EMFV Food Systems and Local Food Curriculum}

\begin{tabular}{|c|c|c|}
\hline Title & Type of Material & Description \\
\hline $\begin{array}{l}\text { The Place Based Nature of } \\
\text { Local Food }\end{array}$ & PowerPoint & $\begin{array}{l}\text { Encourages volunteers to explore the values driving local food system } \\
\text { development in their region. Includes descriptions of the history of food } \\
\text { and farming in different regions of North Carolina. }\end{array}$ \\
\hline $\begin{array}{l}\text { Food Systems: Definitions } \\
\text { and Examples of North } \\
\text { Carolina Projects and } \\
\text { Programs }\end{array}$ & PowerPoint & $\begin{array}{l}\text { Introduces volunteers to a definition of the food system and explores } \\
\text { different types of local food projects and Cooperative Extension programs } \\
\text { in North Carolina according to each sector of the food system. }\end{array}$ \\
\hline $\begin{array}{l}\text { Introduction to Local Food: } \\
\text { Definitions and Common } \\
\text { Questions }\end{array}$ & PowerPoint & $\begin{array}{l}\text { Introduces definitions of local food, addressing why there is rising } \\
\text { consumer interest in local food, and uses common questions about local } \\
\text { food to explore the evidence base for the economic, social, environmental, } \\
\text { and health impacts of local food systems. }\end{array}$ \\
\hline $\begin{array}{l}\text { Standards, Certifications, } \\
\text { and Labels }\end{array}$ & PowerPoint & $\begin{array}{l}\text { Reviews some popular certifications and labels, including organic, animal } \\
\text { welfare, GMOs, fair trade, sustainability practices, and place-based labels. }\end{array}$ \\
\hline Engaging Food Pantries & Video & $\begin{array}{l}\text { Provides an overview of food security definitions and rates for the US and } \\
\text { North Carolina and introduces volunteers to the emergency } \\
\text { food system, including food banks and pantries. }\end{array}$ \\
\hline $\begin{array}{l}\text { Food Systems: What's the } \\
\text { Issue? Activity* }\end{array}$ & Activity & $\begin{array}{l}\text { Asks volunteers to put the sectors of the food system in order and then to } \\
\text { brainstorm different issues and projects that exist nationally, state-wide, } \\
\text { and at the county level for each sector of the food system. }\end{array}$ \\
\hline $\begin{array}{l}\text { Local Food Systems: } \\
\text { Weaving the Web Activity* }\end{array}$ & Activity & $\begin{array}{l}\text { Demonstrates how the food system is like a web, and how local food } \\
\text { systems differ from food systems at other scales. }\end{array}$ \\
\hline $\begin{array}{l}\text { Common Questions } \\
\text { Scenario Activity** }\end{array}$ & Activity & $\begin{array}{l}\text { Gives volunteers a chance to practice how they would respond to } \\
\text { consumer and class participants' questions about local food. }\end{array}$ \\
\hline $\begin{array}{l}\text { Certifications and Labels } \\
\text { Scenario Activity** }\end{array}$ & Activity & $\begin{array}{l}\text { Gives volunteers a chance to practice how they would respond to } \\
\text { consumer and class participants' questions about different types of } \\
\text { standards, certifications, and labels. }\end{array}$ \\
\hline Food Access Activity & Activity & $\begin{array}{l}\text { Includes taking volunteers to a grocery store to shop for a healthy meal on } \\
\text { a limited budget. }\end{array}$ \\
\hline $\begin{array}{l}\text { North Carolina Agricultural } \\
\text { Facts and Commodity } \\
\text { Nutrient Content }\end{array}$ & Handout*** & $\begin{array}{l}\text { Provides an overview of the major North Carolina commodities, including } \\
\text { what season they're grown and basic nutritional content. }\end{array}$ \\
\hline $\begin{array}{l}\text { General Local Food } \\
\text { Resource List }\end{array}$ & Handout & $\begin{array}{l}\text { Includes links to all of the Extension resources referred to in the } \\
\text { PowerPoint presentations. }\end{array}$ \\
\hline $\begin{array}{l}\text { EMFV Reducing Food Waste } \\
\text { Guidance* }\end{array}$ & Handout & $\begin{array}{l}\text { Provides links to resources related to using food waste, including } \\
\text { composting and preparing vegetable broth, that EMFVs can use in } \\
\text { Extension programming and at home. }\end{array}$ \\
\hline How Volunteers Can Engage & Handout & $\begin{array}{l}\text { Explains the different types of activities volunteers could assist with to } \\
\text { engage the public and support their educator around local food system } \\
\text { issues and projects. }\end{array}$ \\
\hline
\end{tabular}


* Developed by an FCS educator in the pilot program.

** Developed in response to pilot evaluation.

$* * *$ In addition to four original handouts listed here that were developed specifically for the EMFV program, the curriculum also includes handouts that were developed by other NC Cooperative Extension programs, as well as seasonality charts from the NC Department of Agriculture \& Consumer Services and handouts from the U.S. Department of Agriculture. Other NC Cooperative Extension publications that are used as handouts include:

- "Best Practices for Utilizing Local Food in Cooking and Nutrition Education Classes" (https://content.ces.ncsu.edu/best-practices-for-utilizing-local-food-in-nutrition-education-and-cooking-classes)

- "Local Food Systems: Clarifying Current Research"

(https://content.ces.ncsu.edu/local-food-systems-clarifying-current-research)

- "Eat Local. Eat Healthy Brochure" (https://localfood.ces.ncsu.edu/wp-content/uploads/2013/10/NCStateCALS-EatLocalFlyer-051117.pdf?fwd=no)

- "NC Choices Quick Guide to Common Label Claims" (https://cefs.ncsu.edu/resources/quick-guide-to-common-label-claims/) 


\section{Appendix B. Select Demographic and Agricultural Characteristics of Pilot Counties}

Table B1. Select Demographic and Agricultural Characteristics of Pilot Counties

\begin{tabular}{|c|c|c|c|c|c|}
\hline & County 1 & County 2 & County 3 & County 4 & County 5 \\
\hline Region of State & Central & Southeast & Northeast & West & Southeast \\
\hline Population (2010) & 39,464 & 107,431 & 23,547 & 67,810 & 122,623 \\
\hline Number of Farms (2012) & 395 & 254 & 82 & 638 & 563 \\
\hline $\begin{array}{l}\text { Percent Change in Female Principal } \\
\text { Operators (PO; 2007-2012) }\end{array}$ & $-46 \%$ & $+8 \%$ & $-16 \%$ & $+54 \%$ & $-33 \%$ \\
\hline $\begin{array}{l}\text { Percent Change in African American } \\
\text { Principal Operators (PO; 2007-2012)) }\end{array}$ & $+50 \%$ & $+74 \%$ & $-50 \%$ & $+100 \%$ a & $-53 \%$ \\
\hline $\begin{array}{l}\text { Percent Change in Number of Farms, } \\
2007-2012\end{array}$ & $-2 \%$ & $-4 \%$ & $+2 \%$ & $-10 \%$ & $-22 \%$ \\
\hline Acres of Farmland (2012) ${ }^{b}$ & 95,299 & 45,422 & 33,356 & 59,540 & 191,195 \\
\hline $\begin{array}{l}\text { Percent Change in Acres of Farmland, } \\
2007-2012\end{array}$ & $-3 \%$ & $+2 \%$ & $+28 \%$ & $-10 \%$ & $+9 \%$ \\
\hline Average Farm Size (acres; 2012) b & 241 & 179 & 431 & 93 & 340 \\
\hline $\begin{array}{l}\text { Percent Change Average Farm Size, } \\
\text { 2007-2012 }\end{array}$ & $-1 \%$ & $+7 \%$ & $+25 \%$ & $0 \%$ & $+40 \%$ \\
\hline $\begin{array}{l}\text { Number of Farmers Market, Roadside } \\
\text { Stands, Produce Markets }\end{array}$ & 2 & 2 & 11 & 4 & 10 \\
\hline $\begin{array}{l}\text { Percent Change in Farms Selling Direct } \\
\text { to Consumers, 2007-2012 }\end{array}$ & $+54 \%$ & $+76 \%$ & $+36 \%$ & $+33 \%$ & $0 \%$ \\
\hline $\begin{array}{l}\text { Direct to Consumer Sales (2012 US } \$ \text {, } \\
\text { unless noted) }\end{array}$ & $\$ 382,000$ & $\begin{array}{l}\$ 139,000 \text { in } \\
2007\end{array}$ & $\$ 276,000$ & $\$ 123,000$ & $\$ 482,000$ \\
\hline $\begin{array}{l}\text { Percent Change in Direct to Consumer } \\
\text { Sales (2007-2012) }\end{array}$ & $+96 \%$ & Unavailable & $+14 \%$ & $-59 \%$ & $+114 \%$ \\
\hline
\end{tabular}

a $-85 \%$ in Native American principal operators

b 1 acre $=0.40$ hectares

Sources: Population demographics are from the U.S. Census, American FactFinder. Agricultural characteristics are from the 2007 and 2012 USDA Census of Agriculture data, compiled by the Center for Environmental Farming Systems in Infographics/County Ag Profiles: https://cefs.ncsu.edu/food-system-initiatives/local-food-economies/infographicscounty-ag-profiles/ 


\section{Appendix C. Interview Guide for FCS Educators}

Now that you've piloted the EMFV program for one year, l'd like to ask you a little about your experiences, and ask for feedback on the various components of the program.

1. Looking back at the agent training that we held last May, what do you think was the most helpful in terms of how you run your program now? How so?

(Probes: Did one section of the curriculum stand out for you? Was there an activity that you especially liked?)

a. What was the least helpful?

b. Is there anything that wasn't covered that you wish we'd included?

2. In terms of planning your next round of volunteer recruitment and training, what do you plan to do differently? What worked well that you'd like to keep the same?

(Probes: This includes recruitment of volunteers, training logistics and topics, online versus in person, etc.)

3. Tell me a little about how the shadowing experience has gone for you and your volunteers.
a. What have volunteers done as part of the shadowing experience?
b. What has worked well, and what would you do differently?

4. What types of activities do you plan on having volunteers assist you with once they are done with the shadowing (or what do they currently do if they have already finished)?

a. What are the areas where you have the most need for volunteer assistance?

5. What do you feel like your volunteers are ready to do, and what areas do you feel like they still need additional training or experience?

a. Are volunteers prepared to help you in the areas where you have the most need for assistance?

6. What are you most excited about for the upcoming year of the EMFV program? Why?

7. Overall, what is one thing you would change about the EMFV program?

8. Overall, what is one thing you would keep the same about the EMFV program?

9. If you had to give advice to an agent just starting the program, what would you tell them?

10. What type of continuing education would you be the most interested in for yourself and your volunteers? (Reminder: We're planning some continuing education modules, including one about working with food pantries, one about working with Faithful Families, one about working with SNAP-Ed, Donation Stations, and one about NC Seafood.) 


\section{Appendix D. Focus Group Guide for EMFV Volunteers}

\section{Topic: Recruitment and Program Orientation}

a. Can you tell me a little about how you learned about the Extension Master Food Volunteer Program? (Probes: Had you already volunteered with your agent? Did you see a press release?)

b. How did the application and interview process go? (Probes: Did the amount of time that the application and interview took seem appropriate? Did the process help you learn more about the program and whether it was a good fit for you?)

c. Tell me a little about the program orientation. (Probe: Did you feel like you learned what you needed to about the history of Extension, what types of programs your agent does, what your role would be, and what forms and procedures you needed to use and follow?)

d. What worked well in the program orientation process?

e. What is one thing you would change about the program orientation process?

f. How do you think the program should be advertised and promoted to volunteers?

\section{Topic: Training and Curriculum}

Let's talk a little about the 30 hours of training. We're interested in learning about your experience with two pieces of that: first, about how the logistics (for example, number of hours, time of day, etc.) of the training worked for you, and second, about the content of the curriculum.

a. Let's talk about the training logistics first.

a.i. How was the training set up? How did that work for your schedule?

(Probes: Was it hard for you to make any of the sessions? How did your agent arrange for make-up classes, and was that effective for you? How did the online portions of the training work for you?)

a.ii. What worked well for you in terms of how the training was set up?

a.iii. What is one thing you would change about how the training was set up?

b. Now let's talk about the curriculum content.

b.i. What was your favorite session or topic? Why?

b.ii. What was your least favorite session or topic? Why? (Reminder: Curriculum content includes Nutrition; Food Safety; Food Systems; Cooking Skills; Cooking Techniques; Teaching Strategies; Diversity, Inclusion, Equity)

b.iii. What was your favorite activity? Why?

b.iv. What was your least favorite activity? Why? (Reminder: Some of the activities include the food systems activity; low-resource shopping activity; cooking demo relay activity; and others that your agent developed)

b.v. Can you tell me more about the other sessions? Was there anything that you wanted to know more about?

b.vi. Was there anything you felt like you didn't need to know to be a volunteer?

b.vii. How did you feel about how the curriculum content was evaluated? As a reminder, this includes post-session evaluation forms, the exam, etc.

(Probes: Did you feel like the post-session evaluation forms captured your knowledge gain? How did you feel about the exam? Our new plan moving forward is to have an assessment before the training, short quizzes after each session, and then a short evaluation focused on satisfaction and confidence after the training. Does that sound like an improvement to you?) 
c. Now let's talk about how you put into practice what you learned.
c.i. Did you feel that you had enough chances to practice teaching or doing cooking demonstrations during the training?
c.ii. After the 30 hours of training, what types of activities did you feel prepared to do?
c.iii. What types of questions did you feel prepared to answer?
c.iv. Are there any areas you have some doubts about?
c.iv.1. What do you feel like you needed as part of your training to be able to feel more confident in this area?

c.v. Can you talk about areas where on-going support might be useful, in addition to the 30 hour curriculum?

d. Is there anything you would change about the training and/or curriculum?

\section{Topic: Shadowing Agent}

a. Tell me a little about your experiences shadowing your agent. What types of activities have you done? (Probe: Have you assisted with classes? Did that include organizing ahead of time, food purchase or preparation of food, or hands-on teaching? Have you assisted with any community events? What events, and how did you help?)

b. What is your favorite part about shadowing your agent?

c. What is your least favorite part about shadowing your agent?

d. Do you feel like there are things that you are doing as part of shadowing your agent that weren't covered in the training?

(Probes: If so, what are those things, and do you think they should be incorporated into the training?)

e. After 30 hours of shadowing your agent, what do you feel ready to do as an Extension Master Food Volunteer?

(Probe: Do you feel ready to do a cooking demonstration on your own, or without the agent present? Do you feel ready to represent Extension? Do you feel ready to assist or teach classes?

f. After 30 hours of shadowing your agent, is there anything you feel less confident doing as an Extension Master Food Volunteer?

g. Is there anything you would change about the shadowing portion of your training?

\section{Topic: Volunteer Activities}

a. Now that you are transitioning from shadowing to being an Extension Master Food Volunteer, what role do you see yourself playing?

(Probe: Do you see yourself primarily supporting your agent? Do you have ideas for new events or programs that you'd like to do within your community?)

b. What is one thing you're most excited about doing as an Extension Master Food Volunteer?

c. What is one thing that you'd prefer not to do as an Extension Master Food Volunteer?

d. How does your agent communicate with you about volunteer opportunities?

\section{Topic: Behavior Changes}

a. Now that you've gone through the program, do you find that there are things you do differently in your own life?

(Probes: For example, have you made any changes to your diet or what you eat? Have you made any changes related to food safety and how you prepare food at home? Do you think about how equity plays a role in your day to day experience?) 


\section{Topic: Continuing Education}

a. What type of continuing education are you most interested in to help support you as a volunteer? (Reminder: We're planning some continuing education modules, including one about working with food pantries, one about working with Faithful Families, one about working with SNAP-Ed, Donation Stations, and one about NC Seafood).

\section{Wrapping Up}

a. Now that you've gone through the program, do you think that you'd be willing to pay a small fee at the beginning of the program to cover costs (ex. Curriculum, apron, nametag, food for training, etc.)?

a.i. If yes, how much do you think would be appropriate?

a.ii. If not, can you explain why?

Those are all of the questions that I have. Is there anything else you'd like to add that I haven't asked about? 


\section{Appendix E. Codebook}

\section{Agent Experience with Food}

$\rightarrow$ Full definition: Agents' experience and comfort level with teaching about food and food systems.

$\rightarrow$ When to Use: Use this code to capture agents' discussions regarding their prior experience or training (or lack thereof) with food and food systems, and how that level of experience may impact their capabilities and comfort level in teaching the parts of the EMFV curriculum related to food and food systems.

\section{Behavior Changes}

$\rightarrow$ Full definition: Changes in agents' and volunteers' behavior as a result of training. Also how agents work with volunteers to facilitate change.

$\rightarrow$ When to Use: Use this code to capture all behavior changes, not just ones associated with the food systems unit. Can be used to capture behavior changes during program (trying new foods, cooking techniques) and at home/outside of the program.

$\rightarrow$ Sub Codes:

- Changes in cooking/preparation of food

- Changes in purchasing

- Food safety

- Trying new foods

\section{Cross-program collaboration}

$\rightarrow$ Full definition: Opportunities for collaboration between program areas and programs to educate audiences on the topic of local food systems.

$\rightarrow$ When to Use: Use this code to refer to when agents/volunteers discuss the potential for programmatic collaboration to implement the local food systems content. Include when they discuss their comfort level with material (when they think they should work with someone else because they don't feel comfortable with the materials) and drawing boundaries around who does what (ag agents, for example).

\section{Definition of Local Food}

$\rightarrow$ Full definition: The definition of local food used by agents and volunteers.

$\rightarrow$ When to Use: Use this code to capture discussions of how volunteer and agents define "local" and "local food," either directly or indirectly. This may be in terms of personal gardens, local markets, region, or state. This code can also capture how the agents/volunteers came up with this definition, and how it may have changed due to the EMFV programming.

\section{Evidence-based Information vs. Personal Opinion}

$\rightarrow$ Full definition: This code refers to the tension identified by agents or volunteers between providing evidence-based information and relying on personal opinion or experiences. Evidence-based information refers to information and content in the EMFV training program that is research-based.

$\rightarrow$ When to Use: This code should be used whenever agents or volunteers identify any potential bias on the part of volunteers (due to personal experience or opinion) in terms of EMFV course content. This includes when agents express concern that volunteers may respond with personal opinion rather than evidence-based information (or give an example of when this may have happened). It can also be used when volunteers discuss their personal opinions on topics, whether or not they refer to the distinction between personal opinion and evidence-based information. 
$\rightarrow$ Sub Codes:

- Controversial topics: organic

- Controversial topics: GMOs

- Controversial topics: pesticides

\section{Food Insecurity}

$\rightarrow$ Full definition: Any reference agents/volunteers make to people who do not have reliable access to affordable and nutritious food.

$\rightarrow$ When to Use: This code can be used capture discussions by agents and volunteers of working with low-income audiences and trying to responsibly educate and discuss with them issues such as the cost of healthy foods (budgeting and affordability) and the nutritional quality of "fresh" food (local vs. canned). This code can also be used to capture the tension between the terms "healthy" and "local," and larger issues surrounding food access in their communities, or more generally (access to stores, resources, transportation).

\section{Food system activities in training curriculum}

$\rightarrow$ Full definition: The activities that were a part of the portion of the EMFV training curriculum on food systems.

$\rightarrow$ When to Use: Use this code to capture discussions of volunteers and agents about the types of activities used to educate volunteers about local food systems. These may include field trips/tours as well as classroom activities.

$\rightarrow$ Sub Codes:

- Food access activity (going to grocery store on limited budget)

\section{History of food system: personal experience}

$\rightarrow$ Full definition: Refers to volunteer discussions of personal experience with various aspects of the food system.

$\rightarrow$ When to Use: Use this code to capture discussions of prior experiences with food (either growing up or present day). This includes gardening and growing one's own food, cooking, food preservation, public health, teaching, and nutrition, etc.

\section{Local food markets}

$\rightarrow$ Full definition: Any reference to where local food is sold and purchased.

$\rightarrow$ When to Use: Use this code to capture agents' and volunteers' knowledge of, experience with, and any behavior changes associated with visiting and/or shopping at local food markets, such as farmers' markets and roadside stands. Includes unfamiliarity or uncertainty about where to purchase local food in their communities. Include any reference to local food markets and supermarkets.

\section{Motivations for participation (volunteers)}

$\rightarrow$ Full definition: The reasons why volunteers chose to participate in the EMFV training program.

$\rightarrow$ When to Use: Use this code to capture the volunteers' discussions of why they chose to train to be an EMFV, including their expectations of the program and if those expectations differed from the actual program content. 


\section{Nutrition and Health}

$\rightarrow$ Full definition: Any reference to agents' or volunteers' understandings of nutrition and healthy food, as well as health concerns and conditions that result from good/bad nutrition.

$\rightarrow$ When to Use: Use this code to capture all discussions of nutrition related to the EMFV program, not just those associated with food systems/local food. This code can also capture discussions of health issues facing individuals or communities outside the context of the EMFV program/curriculum, such as obesity and diabetes, as well as issues of nutrition that are affected by food access and food insecurity.

\section{Program Accessibility}

$\rightarrow$ Full definition: Refers to issues of access to participation in the EMFV program in regards to a lower income audience.

$\rightarrow$ When to Use: Use this code to capture whenever agents or volunteers identify and/or discuss potential barriers to participation on the part of lower income audiences. Examples could include the potential future costs of enrolling in the program; the time commitment; and scheduling.

\section{Readiness/confidence (agents and volunteers)}

$\rightarrow$ Full definition: Refers to when agents and volunteers feel confident and prepared to teach material from the EMFV curriculum or conduct activities independently (in the case of volunteers, without supervision), and when they don't feel ready or confident to do so.

$\rightarrow$ When to Use: Use this code to capture discussions by agents about parts of the curriculum which they do or don't feel confident teaching, as well as when agents are discussing the capabilities of volunteers to transition to independent teaching/activities (and with what subject matter). With volunteers, this code can capture discussions of what activities they feel confident leading on their own, and what activities they do not feel comfortable doing so (and would want more training/education). This code can also capture discussions by both agents and volunteers about moments in which volunteers recognize the limits of their knowledge and should refer questions from the public to the agent.

\section{Volunteer activities in the community}

$\rightarrow$ Full definition: Refers to activities that require volunteers to go into the community to help educate, either as part of their required "shadowing" of an agent or independently. Any reference to what type of activities volunteers are doing (assisting and leading), and any mention of Extension programs they support.

$\rightarrow$ When to Use: Use this code to capture volunteers' discussions of the types of outreach activities they have been doing as part of their training, such as cooking demonstrations, assisting with 4-H camps, community health fairs, senior centers, lunch ' $\mathrm{n}$ learns, etc. This code can also be used to capture volunteers' discussions of community activities that they performed on their own, thus reaching communities that agents do not necessarily have access to. Can also refer to aspirations- what agents or volunteers hope to do in the future. 